\title{
A case of acquired haemolytic anaemia during the early puerperium
}

\author{
T. SINGH* \\ M.B., B.S., M.R.C.P.(Glas.) \\ Wythenshawe Hospital, Manchester 23
}

\section{Introduction}

Acquired haemolytic anaemia arising apparently for the first time during pregnancy or the early puerperium is an uncommon occurrence. Lillie, Gatenby \& Moore (1954) described one such case in 4314 pregnancies, Lescher (1942), Bateman, Hutt \& Norris (1959) and Jankelowitz, Eckerling \& Joshua (1960) each described one case of acute intravascular haemolysis of obscure origin occurring during late pregnancy and Albers (1938), Young (1942), Kistner \& Assali (1956), Pritchard et al. (1953, 1954), Seftal \& Metz (1957), Goodall (1961) and Brain et al. (1968) described cases of acute intravascular haemolysis associated with eclamptogenic toxaemia of pregnancy. Brain (1963) (quoted by Dacie, 1967) described five cases of haemolytic anaemia in women during the early puerperium.

In the case presented here, a haemolytic crisis made its appearance in the early puerperium and responded well to a course of corticosteroids.

\section{Case report}

Mrs K.B., 20 years old, a primigravida having regular antenatal supervision was admitted to Wythenshawe Maternity Hospital under the care of Mr R. H. Martin in October 1968 at 34 weeks gestation because of mild pre-eclampsia with a blood pressure of $160 / 100 \mathrm{mmHg}$, slight ankle oedema and albuminuria. She was treated with bed rest and sedatives for 3 weeks. Artificial rupture of membranes and a syntocinon drip induced labour but due to delay in the second stage, a forceps delivery under local anaesthesia was carried out on 28 October 1968 and a living female infant weighing $7 \mathrm{lb}$ was born. The blood loss during delivery was estimated as $450 \mathrm{ml}$. Haemoglobin on 25 October 1968 was $10.5 \mathrm{~g} / 100 \mathrm{ml}(72 \%)$ with no abnormality in the blood film. On 29 October 1968 she complained of weakness and looked very pale. Haemoglobin level was found to be $4.4 \mathrm{~g} / 100 \mathrm{ml}(30 \%)$ and later dropped to $3.5 \mathrm{~g} / 100 \mathrm{ml}(23 \%)$ on 31 October 1968 . The lochia was of normal appearance and there was no clinical evidence of haemorrhage from any site. On 1 November 1968 she was transfused with 6

\footnotetext{
*Present address: 7/14 South Patel Nagar, New Delhi 8, India.
}

pints of blood (4 pints being packed cells) but the haemoglobin on 5 November 1968 was only $5.4 \mathrm{~g} /$ $100 \mathrm{ml}(37 \%)$. Other haematological findings were్ as follows:

WBC $23,000 / \mathrm{mm}^{3}$, neutrophil polymorphs $86 \%$ metamyelocytes $5 \%$, eosinophils $1 \%$, lymphocytes $7 \%$, monocytes $1 \%$, platelets $10,000 / \mathrm{mm}^{3}$, reticulo $-\overrightarrow{-}$ cytes $15 \%$. In the blood film the red cells showedir anisocytosis and poikilocytosis. There was markedr polychromasia; fragmentation of cells and a numberr of burr cells were also seen and a few normoblasts? (1/100 leucocytes). The polymorphs showed a shift to the left.

The patient was then transferred to the care of Dr C. D. R. Pengelly. Apart from pallor, there were? no abnormal physical signs. Investigations done gn6 November 1968 were as follows:

Hb $5.3 \mathrm{~g} / 100 \mathrm{ml}(36 \%)$, RBC $1.7 \mathrm{million} / \mathrm{mm}^{3}$.

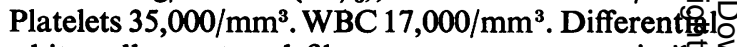
white cell count and film appearances were simifar 3 to those of the previous day. Direct Coombs' testo

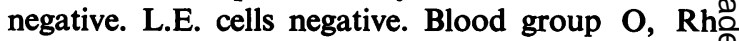
positive. No antibodies in the blood. Schumm's test negative; no free haemoglobin in the plasma. $\overrightarrow{0}$ Serum haptoglobins: none detected. Urinary uro-3 bilinogen: large excess. Serum bilirubin, $2.0 \mathrm{mg} / 100$ ? $\mathrm{ml}$. Serum lactate dehydrogenase $670 \mathrm{~m}$.I. units $/ \mathrm{m}$. at $37^{\circ} \mathrm{C}$ (normal range $70-240$ ). Serum $\alpha$-hydroxy-o butyrate dyhydrogenase $580 \mathrm{~S}$ units $/ \mathrm{ml}$ at $37^{\circ} \mathrm{C}$ (normal range 55-125). Serum glutamateoxaloacetate $\frac{0}{3}$ transaminase $4 \mathrm{~m} . \mathrm{I}$. units $/ \mathrm{ml}$ at $37^{\circ} \mathrm{C}$ (normalrange 5-15). Serum salicylates: none detected. Bone marrow: normoblastic hyperplasia compatible with a reaction to haemolysis.

\section{Management}

The patient was treated with prednisolone com- $N$ mencing with $40 \mathrm{mg} /$ day on 6 November 1968. She N had a further transfusion of 3 pints of blood on N 10 November when the haemoglobin level was still $\sigma$ $4.9 \mathrm{~g} / 100 \mathrm{ml}(34 \%)$. On 12 November the haemoglobin level was $10.0 \mathrm{~g} / 100 \mathrm{ml}(68 \%)$ and the plate- $\frac{0}{0}$ lets $85,000 / \mathrm{mm}^{3}$. Urinary urobilinogen had returned to normal on 18 November. Prednisolone was gradually reduced from 14 November. When discharged 0 from the hospital on 21 November, haemoglobin 


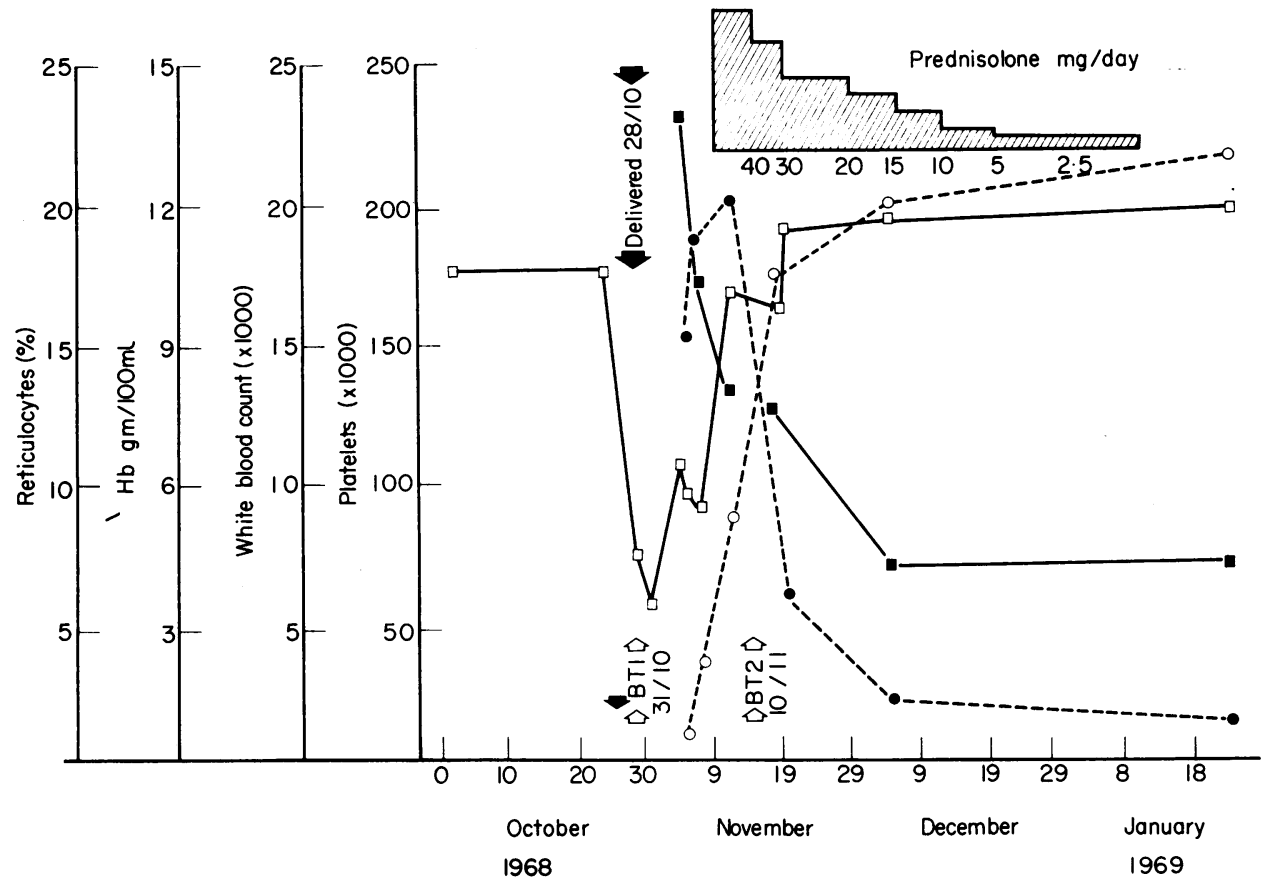

FIG. 1. $\square$, Haemoglobin; O, platelets; $\square$, white cell count; 0 , reticulocytes; BT1 and BT2 = blood transfusions.

was $11.4 \mathrm{~g} / 100 \mathrm{ml}(78 \%)$ and she was"receiving 20 $\mathrm{mg}$ prednisolone per day. This was gradually tailed off over a period of 7 weeks. Platelet count on 23 January 1969 was $215,000 / \mathrm{mm}^{3}$ and when seen in the clinic on 20 February haemoglobin was $13.1 \mathrm{~g} /$ $100 \mathrm{ml}(90 \%)$, reticulocytes $1 \%$. In the blood film, red cells were normocytic, normochromic and no abnormality was present. Estimation of erythrocyte6-phosphate dehydrogenase was delayed because of the large number of immature cells present and on 9 January it was $410 \mathrm{mU} / 10^{9}$. (Normal 140-260 $\mathrm{mU} / 1^{9}$ erythrocytes). The haematological findings are summarized in Fig. 1.

\section{Discussion}

The case presented here shows a definite acute haemolytic syndrome of the acquired type. Following childbirth there was a sudden and rapidly progressive anaemia which did not improve despite adequate blood transfusions. The anaemia was associated with signs of increased red-cell destruction and regeneration, a raised serum bilirubin, increased excretion of urinary urobilinogen, marked reticulocytosis, absent serum haptoglobins, normoblastic proliferation in the bone marrow and a great rise in the serumhydroxy-butyrate dehydrogenase level.

There are numerous possible causes of haemolytic anaemia in pregnancy and the puerperium. Most of those in the literature associated with eclamptogenic toxaemia of pregnancy, proved fatal due to renal failure. Necropsy in these cases showed thrombi within arterioles and capillaries with or without fibrinoid necrosis of arterioles and necrotizing arteritis. Thrombocytopenia was present. Brain, Dacie \& Hourihane (1962) introduced the term microangiopathic haemolytic anaemia for this group of cases. MacWhinney et al. (1962) in a discussion on thrombotic thrombocytopenic purpura drew attention to the similarity between the blood picture in this disease and that in eclampsia and also the similarity of the vascular lesions in the two disorders. The five cases of microangiopathic haemolytic anaemia between the 3rd and 9th day after childbirth described by Brain (1963) also gradually went downhill and died of renal failure. At necropsy fibrinoid necrosis of arterioles associated with partial infarction or cellular proliferation of glomeruli was seen.

Haemolytic anaemia secondary to certain underlying diseases such as leukaemia, malignant lymphoma, Hodgkin's disease (Dacie, 1967a) and exposure to certain drugs such as phenacetin (Dacie 1967b) might occasionally occur during pregnancy. Many of these cases have an autoimmune basis and might then respond to corticosteroid therapy. Besides the above causes of haemolysis during gestation, congenital haemolytic anaemias may 
sometimes become manifest for the first time during pregnancy or the puerperium.

In these cases signs of corpuscular defects such as a high proportion of spherocytes, the sickling phenomenon or abnormal haemoglobins are present.

In the present case there was no evidence of any concomitant disease such as leukaemia or reticulosis or of drug ingestion liable to produce haemolysis. However, she did have mild pre-eclampsia, marked thrombocytopenia, blood urea $55 \mathrm{mg} / 100 \mathrm{ml}$ at the time of the haemolysis, no antibodies in the serum and showed red cell fragmentation and a few burr cells. These findings raise the possibility that this patient might have been a mild example of microangiopathic haemolytic anaemia. Renal biopsy was was not contemplated because of the marked thrombocytopenia.

\section{Acknowledgments}

I am grateful to Mr R. H. Martin for permission to publish the case, Dr C. D. R. Pengelly and Dr K. V. Lodge for their helpful criticism, Dr R. Doshi for the haematological and biochemical investigations, Mr J. W. Firth of the Department of Medical Illustration for help in preparing the graph and Miss R. Jenks for secretarial help.

\section{References}

Albers, H. (1938) Uber eine transitorische intravasale Hamolyse in der Schwangerschaft. Zentralblatt für Gynäkologie, 62, 1823.

Bateman, D.E.R., HutT, M.S.R. \& NorRis, P.R. (1959) A case of haemolytic anaemia in pregnancy. Journal of Obstetrics and Gynaecology of the British Empire, 66, 130.

Brain, M.C., Dacie, J.V. \& Hourihane, D.O'B. (1962) Microangiopathic haemolytic anaemia: the possible role of vascular lesions in pathogenesis. British Journal of Haematology, 8, 358.
BraIN, M.C. (1963) quoted by Dacie, J.V. (1967) The ٌ Haemolytic Anaemias, Congenital and Acquired. p 878. Part 3, 2nd edn. Churchill, London.

BraIN, M.C., BAKer, L.R.I., McBride, J.A., Rubenberg, c M.L. and DACIE, J.V. (1968). Treatment of patients with microangiopathic haemolytic anaemia with heparin. British Journal of Haematology, 15, 603.

DACIE, J.V. (1967a) The Haemolytic Anaemias, Congenital and Acquired. Part 3, 2nd edn. Churchill, London.

DACIE, J.V. (1967b) The Haemolytic Anaemias, Congenital and Acquired. Part 4, 2nd edn. Churchill, London.

Goodall, H.B. (1961) Haemoglobinuria in eclampsia and its relationship to hepatic damage. Pathologica et Microbio- ڤ logica, 24, 602.

Jankelowitz, T., Eckerling, B. \& JoshuA, H. (1960) A case of acquired haemolytic anaemia associated with pregnancy. South African Medical Journal, 34, 911.

KistNeR, R.W. \& Assali, N.S. (1950) Acute intravascular haemolysis and lower nephron nephrosis complicating pregnancy. Annals of Internal Medicine, 33, 221.

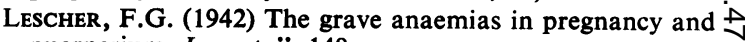
puerperium. Lancet, ii, 148.

Lillie, E.W., Gatenby, P.B.B. \& Moore, H.C. (1954) A survey of anaemia in 4314 cases of pregnancy. Irish Journal of Medical Science, 6th Series. P. 304.

MacWhinney, J.B. JR, PACker, J.T., Miller, G. \& GreenDYKE, R.M. (1962) Thrombotic thrombocytopenic purpura in childhood. Blood, 19, 181.

Pritchard, J.A., Weisman, R. JR, Ratnoff, O.D. \& VosBURGH, G.J. (1953) Intravascular haemolysis, thrombo- ฏ cytopenia and other haematologic abnormalities assog $\frac{\hat{4}}{\partial}$ ated with eclamptogenic toxaemia of pregnancy. Journgl of Laboratory and Clinical Medicine, 42, 929.

Pritchard, J.A., Weisman, R. JR, RatnofF, O.D. \& Vo\&BURGH, G.J. (1954) Intravascular haemolysis, thromb巨్ cytopenia and other haematologic abnormalities associated with severe toxaemia of pregnancy. New England Journal of Medicine, 250, 89.

Seftal, H.C. \& Metz, J. (1957) Haemolytic anaemia. thrombocytopenia and uraemia in eclampsia. South African Medical Journal, 31, 1037.

YouNG, J. (1942) Renal failure after uteroplacental damage, British Medical Journal, 2, 715.

\section{Obesity with cardio-respiratory failure}

\author{
P. DINDA \\ M.B., B.S., M.R.C.P., M.R.C.P.(E.)
}

\author{
W. D. RIDING \\ M.A., M.B., M.R.C.P.
}

\section{S. S. Chatterjee \\ M.B., M.R.C.P.}

Baguley Hospital, Manchester, M 23 9NA

'OBESITY is a condition in which the body contours are distorted by a diffuse accumulation of adipose tissue' (McMullan, 1959). Although obesity is equated with health in some societies, Western civilization is rightly conscious of its numerous complications. Amongst the latter is a clinical syndrome of hypoventilation, pulmonary hypertension, secondary polycy- thaemia and eventual cardiorespiratory failure. The cause of this syndrome is not established but it has been suggested (Carroll, 1956) that excessive fat on the chest and abdominal walls, by interfering with the mechanics of breathing, is a contributory factor. This view is supported by the finding that the abnormalities may be reversed by satisfactory weight loss. 